\title{
Close proximity of the tdh, trh and ure genes on the chromosome of Vibrio parahaemolyticus
}

\author{
Tetsuya lida, Kwon-Sam Park, Orasa Suthienkul, Junji Kozawa, \\ Yoshiharu Yamaichi, Koichiro Yamamoto and Takeshi Honda
}

Author for correspondence: Tetsuya lida. Tel: +816879 8276. Fax: + 8168798277.
e-mail: iida@ biken.osaka-u.ac.jp

Department of Bacterial Infections, Research Institute for Microbial Diseases, Osaka University, 3-1 Yamadaoka, Suita, Osaka 565, Japan

\begin{abstract}
The distribution and location of the virulence-factor genes of Vibrio parahaemolyticus, tdh and trh, and the structural gene of urease, ureC, were examined on the genomic DNAs of 115 clinical isolates of $V$. parahaemolyticus. The majority of strains $(\mathbf{8 1} \%)$ had two copies of $t d h$ on the chromosome, and no copies of trh or ure. Southern hybridization with a tdh probe, after pulsedfield gel electrophoresis of Notl-digested genomic DNA of each strain revealed only single bands, suggesting that the two copies of $t d h$ exist on single Notl fragments in each strain. Of the 115 strains, $7 \%$ had the $t d h$, trh and ure genes on chromosomal DNA. The three genes were also detected on single NotI fragments in these strains. More detailed analysis revealed that the three genes were localized within $40 \mathrm{~kb}$. By long and accurate polymerase chain reactions (LA-PCR), the distance between trh and ure was shown to be less than $8.5 \mathrm{~kb}$. These results reveal a close proximity of the $t d h, t r h$ and ure genes on the chromosome of pathogenic V. parahaemolyticus strains.
\end{abstract}

Keywords: Vibrio parahaemolyticus, $t d h$, trh, ure, virulence-factor genes

\section{INTRODUCTION}

Vibrio parahaemolyticus is an important cause of seafood-related gastroenteritis and traveller's diarrhoea (Honda \& Iida, 1993). V. parahaemolyticus strains isolated from diarrhoeal patients produce either the thermostable direct haemolysin $(\mathrm{TDH})$ or the TDHrelated haemolysin (TRH) or both, while almost all isolates from the environment do not produce these haemolysins (Honda \& Iida, 1993). TDH and TRH, encoded by $t d h$ and $t r h$, respectively, are each composed of 165 amino acids and share an approximately $67 \%$ identity in their amino acid sequences. Biochemical, epidemiological and genetic studies have shown that the two haemolysins contribute to the pathogenicity of the organisms (Honda \& Iida, 1993; Honda et al., 1990b; Nishibuchi et al., 1992; Sakazaki et al., 1968; Shirai et al., 1990; Xu et al., 1994). Several lines of evidence suggest that at some time in the past, the $t d h$ gene (and possibly trh also) was acquired by ancestral $V$. parahaemolyticus strains from another organism through genetic transfer events mediated by insertion-

Abbreviations: $L A-P C R$, long and accurate polymerase chain reaction; $\mathrm{TDH}$, thermostable direct haemolysin; TRH, TDH-related haemolysin. sequence-like elements (Terai et al., 1991; Nishibuchi \& Kaper, 1995).

Although $V$. parahaemolyticus does not generally produce urease, there have been some reports of clinical isolates that produce this enzyme. We recently demonstrated that the urease-positive phenotype of V. parahaemolyticus strains is always associated with the possession of the trh gene (Suthienkul et al., 1995), and that the association is due to a genetic linkage between the structural gene of urease (ure) and trh on the chromosome of $V$. parahaemolyticus strains (Iida et al., 1997).

In this study, to provide insight into the putative ancient transfer of virulence-factor genes, we analysed the distribution of the $t d h, t r h$ and ure genes among clinically isolated $V$. parabaemolyticus strains, and determined the location of the genes on the genomic DNA.

\section{METHODS}

Bacterial strains. The $115 \mathrm{~V}$. parahaemolyticus strains used in this study were isolated from patients with traveller's diarrhoea at the Osaka International Airport quarantine station from October 1991 to October 1992. The countries and areas 
from which the patients are thought to have become infected by $V$. parabaemolyticus are diverse, including Hong Kong, South Korea, Thailand, the Philippines, Indonesia, Singapore, Taiwan, Vietnam, Malaysia, India, China, and the Maldives. Urease production by these strains was examined as previously described (Suthienkul et al., 1995).

Nucleic acid techniques. Southern hybridization was performed with probes specific for $t d h$ or $t r h$ as previously described (Suthienkul et al., 1996). The probes were labelled with digoxigenin-11-dUTP using a random primer extension method provided by a DNA labelling and detection kit (Boehringer Mannheim). Labelling was done according to the manufacturer's protocol. The labelled DNA fragments were separated from unincorporated nucleotides by ethanol precipitation and redissolved in TE buffer $(10 \mathrm{mM}$ Tris $/ \mathrm{HCl}$, $1 \mathrm{mM}$ EDTA, pH 8.0), then stored at $-20^{\circ} \mathrm{C}$ until use. For the $t d h$ genes, the hybridization temperature was $37^{\circ} \mathrm{C}$, and for the trh genes, either less or more stringent conditions were used as previously described (Suthienkul et al., 1996). Restriction enzymes were purchased from Toyobo. Extraction of genomic (Wilson, 1987) and plasmid (Kado \& Liu, 1981) DNA from $V$. parahaemolyticus was performed as previously described.

Possession of $\boldsymbol{t} d \boldsymbol{h}$ and trh genes. The presence or absence of $t d h$ and $t r h$ genes in V.parahaemolyticus strains was examined by Southern hybridization as described above. For the trh gene, hybridization was done in less stringent conditions.

Pulsed-field gel electrophoresis (PFGE). Samples for PFGE were prepared as described by Smith \& Cantor (1987) with minor modification. Briefly, bacterial cells were grown overnight with shaking at $37^{\circ} \mathrm{C}$ in $\mathrm{LB}$ broth containing $3 \% \mathrm{NaCl}$. Cells were then harvested by centrifugation, resuspended with $10 \mathrm{mM}$ Tris/ $\mathrm{HCl}$ ( $\mathrm{pH} 8.0$ ), $1 \mathrm{M} \mathrm{NaCl}, 50 \mathrm{mM}$ EDTA, and mixed with an equal volume of molten low-melting-point $1.6 \%$ agarose (LMP Agarose; Life Technologies). Agarose blocks were incubated for $2 \mathrm{~h}$ at $37^{\circ} \mathrm{C}$ in lysozyme solution [1 mg lysozyme $\mathrm{ml}^{-1}$ in $10 \mathrm{mM}$ Tris $/ \mathrm{HCl}(\mathrm{pH} \mathrm{8.0)}, 1 \mathrm{M} \mathrm{NaCl}$, $100 \mathrm{mM}$ EDTA, $0 \cdot 2 \%$ sodium deoxycholate, $0.5 \%$ sodium lauroylsarcosine (SLS), $2 \mu \mathrm{g}$ RNase $\mathrm{ml}^{-1}$ ] and then deproteinated in $1 \mathrm{mg}$ proteinase $\mathrm{K} \mathrm{ml}^{-1}$ in $0.5 \mathrm{M}$ EDTA $(\mathrm{pH}$ $8.0), 1 \%$ SLS at $50{ }^{\circ} \mathrm{C}$ overnight. Cell debris and proteinase $\mathrm{K}$ were then removed in a sequence of four $2 \mathrm{~h}$ washes: washes 1,3 , and 4 were in $20 \mathrm{mM}$ Tris/ $\mathrm{HCl}\langle\mathrm{pH} 8.0\rangle, 50 \mathrm{mM}$ EDTA at room temperature; wash 2 was in the same solution containing $1 \mathrm{mM}$ phenylmethylsulphonyl fluoride (Sigma). The V.parahaemolyticus DNA in agarose blocks was digested with restriction enzymes described in the text. PFGE was performed as previously described (Iida et al., 1997) using a contour-clamped homogeneous electric field method on a CHEF DR III System (Bio-Rad). Southern hybridization after PFGE was carried out by a previously described method (Iida et al., 1997). The probe for the V. parabaemolyticus ure gene has been previously described (Iida et al., 1997).

PCR. Following the manufacturer's instructions, long and accurate polymerase chain reaction (LA-PCR) was performed using the LA PCR kit version 2 (Takara Shuzo). Oligonucleotide primers were synthesized using an Applied Biosystems DNA synthesizer, model 381A. The oligonucleotide primers for PCR between trh and ure C were p83 (trh-sense: $5^{\prime}$-GGCTCAAAATGGTTAAGCG-3'), p84 (trh-antisense: 5'-CATTTCCGCTCTCATATGC-3'), URE5 (ureC-sense: $5^{\prime}$-ACTAATGCTACAACAGTCAC-3') and URE6 (ureCantisense: $5^{\prime}$-ATGCTGGAATGATGTTAGGT-3'). The design of URE5 and URE6 was based on the partial nucleotide sequence of the $V$. parabaemolyticus ure $C$ gene that we determined in previous work (Iida et al., 1997). Extracted genomic DNA (100 ng) from V. parahaemolyticus AQ4673 was used as a template for PCR in a scale of $50 \mu \mathrm{l}$ reaction solution. PCR conditions were as follows. After heating at $94^{\circ} \mathrm{C}$ for $1 \mathrm{~min}$, a cycle of $98^{\circ} \mathrm{C}$ for $10 \mathrm{~s}, 55^{\circ} \mathrm{C}$ for $10 \mathrm{~s}$, and $68^{\circ} \mathrm{C}$ for $15 \mathrm{~min}$ was repeated 30 times. This was followed by an extension step at $72^{\circ} \mathrm{C}$ for $10 \mathrm{~min}$. The PCR was done on a Perkin Elmer thermal cycler type 9600. Amplified DNA fragments were detected by ethidium bromide staining after agarose gel electrophoresis on $0.8 \%$ gels.

\section{RESULTS}

\section{Distribution of $t d h$ and trh}

First, to determine the distribution of $t d b$ and $t r h$ in clinical $V$. parahaemolyticus strains, we examined the presence or the absence of the two genes in a total of 115 $V$. parahaemolyticus strains isolated from diarrhoeal patients at the Osaka International Airport quarantine station. The results showed that 106 strains $(92 \cdot 2 \%)$ possessed $t d h$ and that 19 strains $(16.5 \%)$ had $t r h$. Eleven strains $(9 \cdot 6 \%)$ were positive for both $t d h$ and $t r h$, and only one strain $(0.9 \%)$ had neither $t d h$ nor $t r h$.

\section{Clonal relationships among strains}

To analyse the clonal relationships among the $V$. parahaemolyticus strains, restriction fragment length polymorphism of $t d h$ and $t r h$ was examined. A previously described Southern hybridization method (Suthienkul et al., 1996) was employed to examine the genomic DNA after it was digested with HindIII and the DNA fragments were hybridized with $t d h$ and $t r h$ probes. Strains possessing $t d h$ were divided into six types, D1, D2, D3, D6, D7 and D8, depending on differences in the restriction fragment patterns (Fig. 1, Table 1). Some $t d h$ genes were found on plasmid DNA (Fig. 1b). trh-possessing strains were divided into four types, R1, R2, R3 and R4, as previously reported for Thai isolates (Suthienkul et al., 1996) (Table 1), but some $t r h$ bands in type R1 strains hybridized with the $t r h$ probe only in less stringent conditions (Table 1). All the trh bands existed exclusively on chromosomal but not on plasmid DNA (data not shown).

The chromosomal and episomal distribution for $t d h$ and trh among the tested strains is summarized as follows: 93 strains had two copies of $t d b$ on the chromosome and no $t r h$ (this group contains the type D1/None strains, i.e. those having the type $\mathrm{D} 1 t d h$ and no $t r h$ ), one strain had one copy of $t d h$ on the chromosome and no trh (D7/None), one strain had one $t d h$ on a plasmid and no trh (D8/None), eight strains had one trh on the chromosome (None/R1, None/R3 and None/R4), eight strains had one $t d h$ and one $t r h$ both on the chromosome (D2/R2 and D6/R1), three strains had one trb on the chromosome and one $t d b$ on plasmid (D3/R4), and one strain had neither $t d b$ nor trh (None/None). These results suggest that in the majority of the strains, $t d h$ and trh are present on the chromosomal DNA. 
(a)

$\begin{array}{llllllll}1 & 2 & 3 & 4 & 5 & 6 & 7 & 8\end{array}$

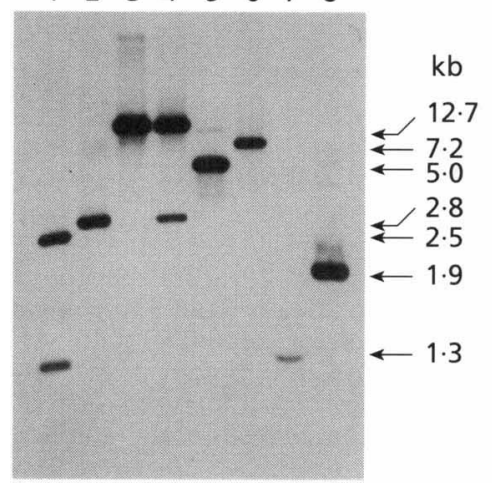

(b)

$\begin{array}{llllllll}1 & 2 & 3 & 4 & 5 & 6 & 7 & 8\end{array}$

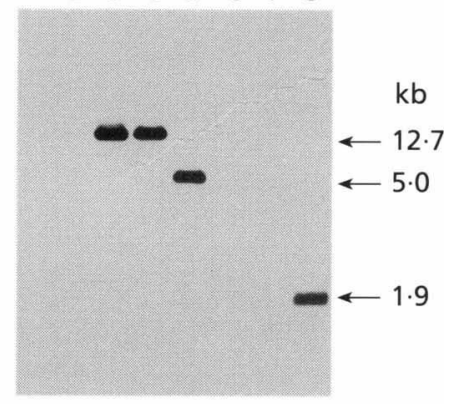

Fig. 1. Eight types of HindllI restriction fragment pattern of $t d h$ in representative strains. (a) Genomic DNA; (b) plasmid DNA. The lanes contain the following types of restriction fragment patterns: $1, D 1 ; 2, D 2$; 3, D3; 4, D4; 5, D5; 6, D6; 7, D7; 8, D8. Types D4 and D5, which were previously observed among Thai isolates (Suthienkul et al., 1996), were not found in this study. The $t d h$ bands in types D3, D5 and D8, and one of two bands in type D4, were on plasmid DNA since the extracted plasmid fractions showed the same positive reaction with the $t d h$ probe as in (b). Hybridization with the $t d h$ probe was performed at $37{ }^{\circ} \mathrm{C}$ as described previously (Suthienkul et al., 1996).

Table 1. Relationships among the types of HindIII restriction fragment pattern (RFP) for $t d h$ and trh in clinical $V$. parahaemolyticus isolates at Osaka Airport

The numbers in parentheses represent the number of strains that hybridized with the trh probe only in less stringent conditions (Suthienkul et al., 1996).

\begin{tabular}{|c|c|c|c|c|c|c|c|c|}
\hline \multirow{2}{*}{$\begin{array}{l}\text { RFP of } \\
\text { trh type: }\end{array}$} & \multicolumn{8}{|c|}{ No. of strains whose RFP of $t d h$ was type: } \\
\hline & None* & D1 & D2 & D3 & D6 & D7 & D8 & Total \\
\hline Nonet & 1 & 93 & 0 & 0 & 0 & 1 & 1 & 96 \\
\hline $\mathrm{R} 1$ & $5(3)$ & 0 & 0 & 0 & 1 & 0 & 0 & 6 \\
\hline $\mathrm{R} 2$ & 0 & 0 & 7 & 0 & 0 & 0 & 0 & 7 \\
\hline R3 & $2(2)$ & 0 & 0 & 0 & 0 & 0 & 0 & 2 \\
\hline R4 & $1(1)$ & 0 & 0 & $3(3)$ & 0 & 0 & 0 & 4 \\
\hline Total & 9 & 93 & 7 & 3 & 1 & 1 & 1 & 115 \\
\hline
\end{tabular}

"None, a type that produced no $t d h$ bands.

† None, a type that produced no trh bands.

(a)

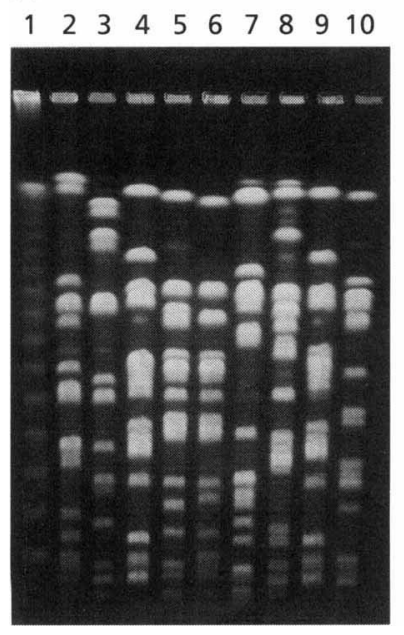

(b)

$\begin{array}{llllllllll}1 & 2 & 3 & 4 & 5 & 6 & 7 & 8 & 9 & 10\end{array}$

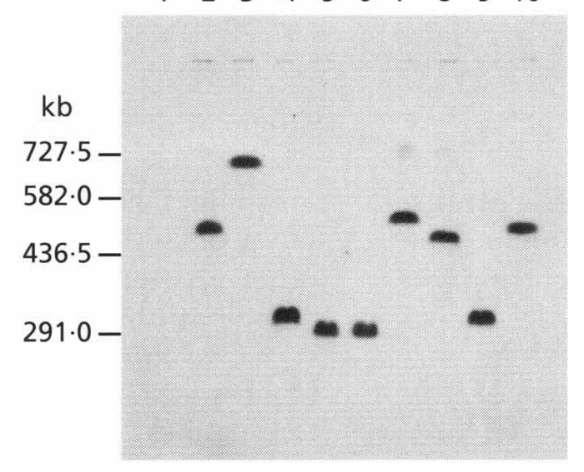

Fig. 2. PFGE of Notl-digested genomic DNA of $V$. parahaemolyticus strains possessing only $t d h$. Electrophoresis was performed with an electric field of $6.0 \mathrm{~V} \mathrm{~cm}^{-1}$ on $1 \%$ agarose gels in $1 \times$ TBE buffer at $14^{\circ} \mathrm{C}$. The pulse times increased linearly from 5 to $50 \mathrm{~s}$ within $24 \mathrm{~h}$. (a) Ethidium bromide staining; (b) Southern hybridization with a tdh probe. Lane 1, Molecular size markers, lambda ladder (concatemers of $\lambda$ c1857sam7; band sizes are 48.5, 97, $145.5 \mathrm{~kb}$, etc., from bottom to top); lanes 2-10, $\mathrm{V}$. parahaemolyticus strains AQ4680, AQ4690, AQ4700, AQ4710, AQ4730, AQ4740, AQ4750, AQ4760 and AQ4780, respectively. All the strains possess only $t d h$, and belong to the D1/None type.

\section{Two copies of $t d h$ in type D1/None strains are on single Notl fragments}

The predominant type of strain, D1/None, had two copies of $t d h$ on the chromosome (Fig. 1). Some other types of strain had both $t d h$ and $t r h$ on chromosomal
DNA : for example, D2/R2 and D6/R1. Consequently, we analysed the relative location of the genes on chromosomal DNA using PFGE followed by Southern hybridization.

Fig. 2 shows data on the genomic DNA from type 
(a)

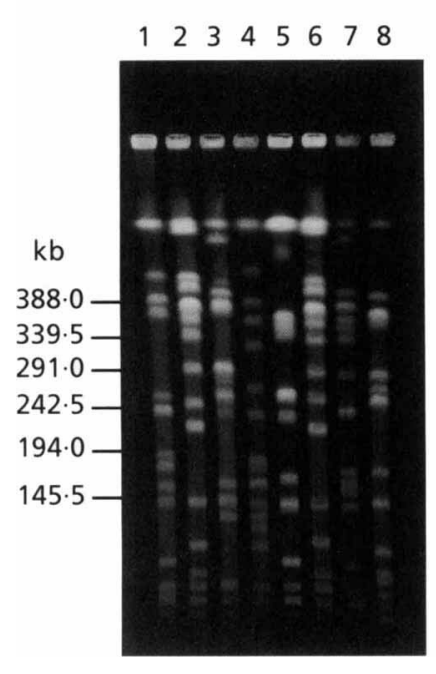

(b)

$$
\begin{array}{llllllll}
1 & 2 & 3 & 4 & 5 & 6 & 7 & 8
\end{array}
$$

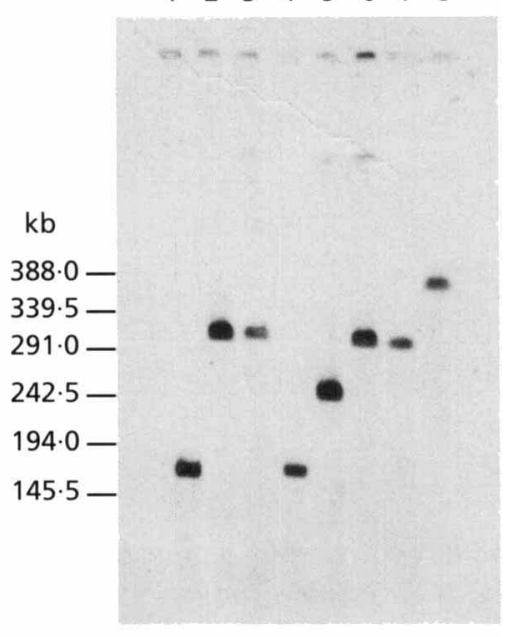

Fig. 3. PFGE of Notl-digested genomic DNA of $V$. parahaemolyticus strains possessing both tdh and trh. Electrophoresis was performed as in Fig. 2, except that the pulse times increased linearly from 5 to $50 \mathrm{~s}$ within $22 \mathrm{~h}$. (a) Ethidium bromide staining; (b) Southern hybridization with a tdh probe. The results of hybridization with a trh probe or a urec probe were basically identical to those with the tdh probe (data not shown). Lanes 1-8, AQ4673, AQ4686, AQ4696, $\mathrm{AQ4713,AQ4758,AQ4761,AQ4781} \mathrm{and}$ AQ4739, respectively. AQ4739 belongs to the D6/R1 type, and the other strains to the D2/R2 type. (a)

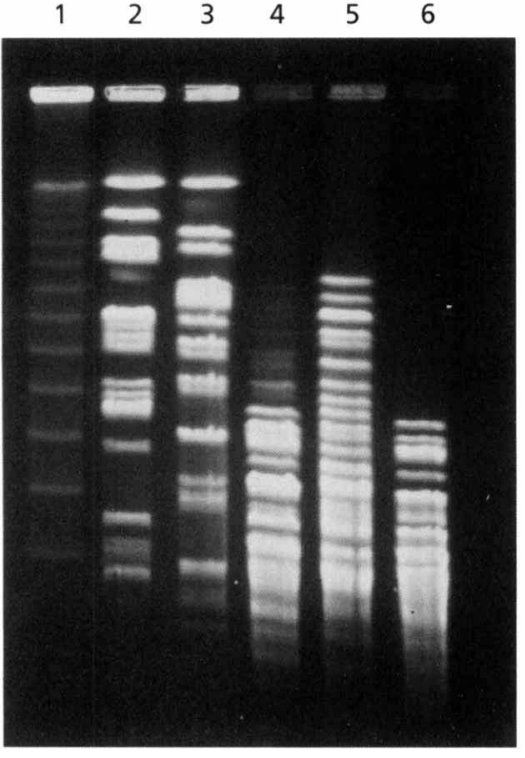

(b)

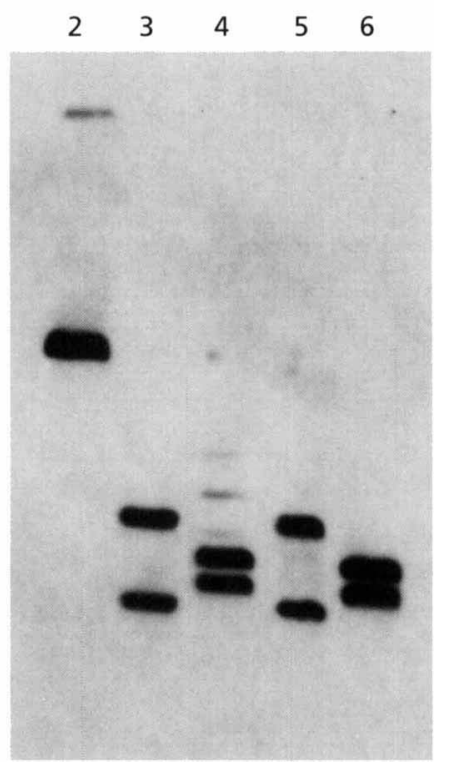

Fig. 4. PFGE of the restriction-enzyme-digested genomic DNA of $V$. parahaemolyticus strain AQ4700, which possesses only $t d h$. Electrophoresis was performed as in Fig. 2 , except that the pulse times increased linearly from 1 to $40 \mathrm{~s}$ within $20 \mathrm{~h}$. (a) Ethidium bromide staining; (b) Southern hybridization with a $t d h$ probe. Lane 1, Molecular size markers, lambda ladder (concatemers of $\lambda$ c1857sam7: band sizes are $48.5,97,145.5 \mathrm{~kb}$, etc., from bottom to top). Genomic DNA of $V$. parahaemolyticus strain AQ4700 was digested with Notl (lane 2), Sfil (lane 3), Smal (lane 4), Notl and Sfil (lane 5), and Notl and Smal (lane 6).
D1/None strains and Fig. 3 shows data for strains possessing both $t d h$ and $t r h$ on the chromosome. The genomic DNA was digested with a rare-cutting restriction enzyme, NotI. The ethidium-bromide-stained DNA patterns (Figs $2 \mathrm{a}$ and $3 \mathrm{a}$ ) had no obvious correlation with the HindIII fragment patterns of $t d h$ and/or trh (Fig. 1, Table 1).

After Southern hybridization with the $t d h$ probe, the NotI-digested genomic DNA of each of the type D1/None strains showed only one band (Fig. 2b). This result was unexpected since these strains have two copies of $t d h$ (Fig. 1a). This indicates that, in each of the type D1/None strains, two copies of $t d h$ exist on single NotI fragments. The size of the NotI fragments that possessed the $t d h$ varied, but was within the range $300-700 \mathrm{~kb}$. This means that for type D1/None strains, the distance between the two copies of $t d h$ on chro- mosomal DNA is less than this range. When the genomic DNA of AQ4700, a D1/None strain, was digested with other restriction enzymes such as $S f I$ or $S m a I$, or with combinations of enzymes with NotI, in all cases the two copies of $t d h$ were detected on distinct bands, and each band was $40-100 \mathrm{~kb}$ in size (Fig. 4). Thus, although the two copies of $t d h$ are close to each other on the chromosome (Fig. 2), the distance between the two does not seem to be near as that between $t d h$ and $t r h$ of the type D2/R2 strain (see below).

\section{tdh and trh in types D2/R2 and D6/R1 strains are also on single Notl fragments}

Strains possessing both $t d h$ and $t r h$ on the chromosome were also examined (Fig. 3). After PFGE, the NotI digests of the genomic DNA of those strains were 


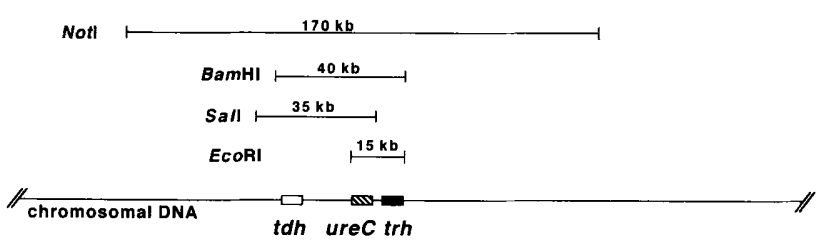

Fig. 5. Relative location of the $t d h$, ure $C$ and trh genes on the chromosome of $V$. parahaemolyticus AQ4673 as determined by Southern hybridization. Genomic DNA was digested with the indicated restriction enzymes, then the ure, trh or tdh gene was detected by Southern hybridization after PFGE. Electrophoresis was performed with an electric field of $6.0 \mathrm{~V} \mathrm{~cm}-1$ on $1 \%$ agarose gels in $1 \times$ TBE buffer at $14^{\circ} \mathrm{C}$. The pulse times increased linearly from 2 to $20 \mathrm{~s}$ within $12 \mathrm{~h}$.

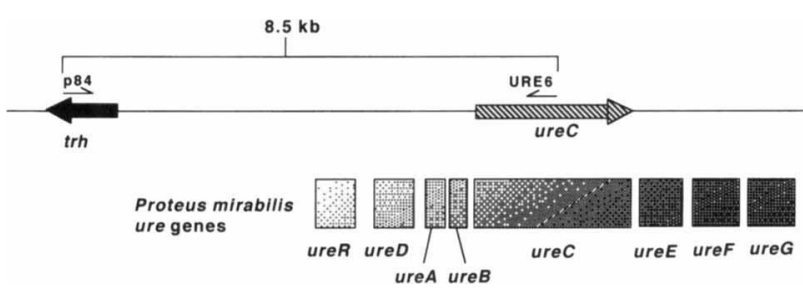

Fig. 6. Schematic representation of the relative location and direction of the trh and ure $C$ genes on the chromosome of $V$. parahaemolyticus AQ4673. For comparison, the rough organization of the ure gene cluster of Proteus mirabilis (Nicholson et al., 1993) is indicated at the bottom.

hybridized with the $t d h$ or $t r h$ probe. In each of the strains, the probes for $t d h$ and $t r h$ hybridized with common single bands, ranging from 150 to $350 \mathrm{~kb}$ in size. These results suggest that the two genes exist within this range on the chromosomal DNA of the strains tested.

\section{Close proximity of $t d h$, trh and ureC in types D2/R2 and D6/R1 strains}

Previously, we have shown that the urease-producing phenotype of $V$. parahaemolyticus isolated in Thailand is completely coincident with the possession of $t r h$, and that this is due to a genetic linkage between $t r h$ and ure (Suthienkul et al., 1995; Iida et al., 1997). We investigated whether this was also the case with the strains tested in this study. All the trh-possessing strains were shown to produce urease, while none of the $t r h$-negative strains produced the enzyme (data not shown). Thus, the coincidence of possession of trh and urease-producing phenotype was confirmed with the strains used in this study. Since we had discovered that ure was present only in the chromosome but not on a plasmid (Iida et al., 1997), we analysed the relative locations of $t r h$ and ure on the chromosome of the strains in this study. PFGE followed by Southern hybridization with a probe (Iida et al., 1997) for a structural gene of urease, ureC (Mobley et al., 1995) demonstrated that, in strains possessing both $t d h$ and $t r h, u r e C$ was on the same Not Iragments as $t d h$ and trh (Fig. 3). More detailed analysis, using more frequently cutting restriction enzymes than NotI, of the distance and location of $t d h, t r h$ and $u r e C$ was done on strain AQ4673, which possesses all the three genes on the chromosome (type D2/R2) (data not shown). The results showed that the three genes were on a common BamHI fragment of approximately $40 \mathrm{~kb}$. When EcoRI was used for digestion, trh and ureC appeared to be on a similar fragment of approximately $15 \mathrm{~kb}$, but $t d h$ was on an obviously distinct EcoRI fragment. When DNA was digested with HindIII, each gene was found on distinct fragments. We have schematically summarized these data in Fig. 5.

\section{Distance between trh and ureC}

Since the distance between trh and ureC in strain AQ4673 was apparently less than $15 \mathrm{~kb}$ (Fig. 5), we attempted to determine the exact distance between the two genes by means of LA-PCR. To cover all the four possibilities of relative directions between trh and ureC, we tried four combinations of primers, p83/URE5, p83/URE6, p84/URE5 and p84/URE6 (p83 and p84 are primers for $t r h$, and URE5 and URE6 for ureC). Only one combination of primers (p84/URE6) amplified a single DNA fragment after PCR, when tested with the genomic DNA of AQ4673 (data not shown). The size of the amplified fragment was approximately $8.5 \mathrm{~kb}$. Taking into account the positions of the primers and the hitherto unknown open reading frames between $t r h$ and ure $C$, since the genes that are required for the biosynthesis of urease normally make up clusters (Mobley et al., 1995), the distance between the trh and urease gene cluster should be only a few kilobases. Fig. 6 presents a schematic representation of the relative location of trh and ure.

\section{DISCUSSION}

$V$. parahaemolyticus is a causative agent of gastroenteritis, especially associated with consumption of seafood (Honda \& Iida, 1993). V. parabaemolyticus is a normal marine inhabitant, and most environmental isolates are non-pathogenic to humans. It has generally been considered that only a part of the population of $V$. parahaemolyticus has ability to cause human gastroenteritis. To discriminate the pathogenic and nonpathogenic strains, a blood agar medium designated Wagatsuma agar was devised. On plates of this medium, almost all the strains isolated from the diarrhoeal faeces of patients give clear haemolysis, while environmental isolates are non-haemolytic (Sakazaki et al., 1968; Miyamoto et al., 1969). The haemolysis on Wagatsuma agar was named as the Kanagawa phenomenon, and it has been used to discriminate pathogenic $V$. parahaemolyticus strains. TDH is a protein toxin which has been identified as the agent responsible for the Kanagawa phenomenon and thus has been recognized as an important virulence factor of $V$. parahaemolyticus. Honda et al. (1988) found that clinical isolates of $V$. parabaemolyticus with a Kanagawa-phenomenon-nega- 
tive phenotype, a rare phenotype among clinical isolates of the organism, produce TDH-related haemolysin (TRH). The amino acid sequence of TRH is approximately $67 \%$ identical to TDH, and TRH has similar biological activities such as haemolytic activity, cytotoxicity, cardiotoxicity and enterotoxicity (Honda \& Iida, 1993). Thus, TRH is also believed to be an important virulence factor in Kanagawa-phenomenonnegative $V$. parahaemolyticus. Several groups of researchers have examined the distribution of the genes that encode TDH $(t d h)$ and TRH $(t r h)$ in clinical and environmental isolates (Shirai et al., 1990; Suthienkul et al., 1995; Osawa et al., 1996). In general, most clinical $V$. parahaemolyticus strains possess $t d h$, while few environmental strains do. Although strains possessing trh are occasionally isolated from the environment (seawater and seafood, etc.), they are also almost exclusively found in clinical samples (Shirai et al., 1990; Honda et al., 1990a, 1992). By homologous recombination techniques, the contribution of TDH and TRH to the diarrhoeagenicity of $V$. parahaemolyticus has been demonstrated (Nishibuchi et al., 1992; Xu et al., 1994).

In this study, we have demonstrated that $t d h$ and $t r h$ are closely linked on the chromosome in V. parahaemolyticus strains that possess both genes. This result was unexpected, because the distributions of the two genes in clinical $V$. parabaemolyticus strains seem to be almost independent of each other (this study; Suthienkul et al., 1995). The strong association observed between the restriction fragment patterns of $t d h$ and $t r h$ (Table 1 ; Suthienkul et al., 1996) might be partly related to the linkage of the two genes on chromosome.

In addition to the relation between $t d h$ and trh, the relation between trh and ure genes also provided interesting results. We have previously reported on the complete association of a urease-producing phenotype with the possession of $t r h$ (Suthienkul et al., 1995), and several other groups have reported similar findings for clinical V. parahaemolyticus strains (Magalhaes et al., 1992; Obata et al., 1996; Okuda et al., 1997; Osawa et al., 1996; Suzuki et al., 1995). More recently, we demonstrated that the association is due to a genetic linkage between the urease structural gene (ure) and trh in V. parahaemolyticus strains (Iida et al., 1997). In this study, we further analysed the relative location of the ure and trh genes on the chromosome, and determined the distance between the two genes. The results of LAPCR have revealed that the distance is within a range of a few kilobases. These results confirm the genetic linkage between trh and ure. The observed genetic linkage suggests the possibility that trh and ure were involved in a gene-transfer event in the past (see below).

The clustering of virulence genes on chromosomal DNA was recently reported for several pathogenic bacteria, such as uropathogenic and enteropathogenic Escherichia coli, Salmonella species, Yersinia pestis and Helicobacter pylori (Groisman \& Ochman, 1996). Usually, the clustering regions, or pathogenicity islands, have a considerably lower GC content than that of the entire genomic DNA of the bacteria in which they are found. This suggests that they were somehow transferred into those pathogenic organisms from another organism. The mechanisms are unknown, but one possibility involves a bacteriophage-mediated process. The close proximity of $t d h, t r h$ and $u r e$ (in D2/R2 and D6/R1 strains) and two copies of $t d b$ (in D1/None strains) on chromosomal DNA of clinical V. parahaemolyticus strains as demonstrated in this study seems to suggest that pathogenic $V$. parahaemolyticus strains also have a clustering of virulence genes on the chromosome. The fact that the GC content of $t d h$ and $t r h$ is considerably lower than the mean GC content of the genomic DNA of $V$. parahaemolyticus (Iida \& Yamamoto, 1990; Nishibuchi \& Kaper, 1995) tempts us to consider the possibility that pathogenic $V$. parahaemolyticus might have a pathogenicity island on the chromosome. However, further evidence is needed to establish this. Nishibuchi and his colleagues, on the other hand, reported that $t d b$ is flanked by sequences homologous to insertion sequences (Terai et al., 1991), and suggested that pathogenic $V$. parahaemolyticus acquired the $t d b$ gene through a mechanisim involving the insertion sequences (Nishibuchi \& Kaper, 1995). More precise localization of $t d h, t r h$ and ure and determination of the nucleotide sequences around the genes, which we are currently involved in, could reveal the way in which the gene transfer events happened in the past.

Although TDH and TRH are believed to be the primary virulence factors of $V$. parabaemolyticus in gastroenteritis infection, the enterotoxicity of purified TDH and TRH is not strong enough in itself to cause the severe clinical symptoms of pathogenic V. parahaemolyticus. For example, the quantity of TDH (or TRH) needed to cause a level of fluid accumulation similar to cholera toxin, a strong diarrhoeagenic protein toxin, in a rabbit ligated ileal loop model, was several hundred times more than that of cholera toxin (Honda et al., 1990b). Thus, although we cannot exclude the contribution of TDH and TRH to the pathogenicity of $V$. parahaemolyticus, we must also look for extra factor(s) that contribute to the pathogenicity of the organism. If pathogenic $V$. parahaemolyticus strains have clusters of virulence genes on their chromosomal DNA, more precise and extensive analyses of the regions around $t d h$ and $t r h$ may reveal virulence factor genes of V. parahaemolyticus that are as yet unknown.

\section{ACKNOWLEDGEMENTS}

This work was supported by a grant-in-aid for Scientific Research from the Ministry of Education, Science and Culture of Japan.

\section{REFERENCES}

Groisman, E. A. \& Ochman, H. (1996). Pathogenicity islands: bacterial evolution in quantum leaps. Cell 87, 791-794. 
Honda, S., Matsumoto, S., Miwatani, T. \& Honda, T. (1992). A survey of urease-positive Vibrio parabaemolyticus strains isolated from traveller's diarrhea, sea water and imported frozen sea foods. Eur J Epidemiol 8, 861-864.

Honda, T. \& lida, T. (1993). The pathogenicity of Vibrio parabaemolyticus and the role of the thermostable direct haemolysin and related haemolysins. Rev Med Microbiol 4, 106-113.

Honda, T., Ni, Y. \& Miwatani, T. (1988). Characterization of a hemolysin produced by a clinical isolate of Kanagawa phenomenon-negative Vibrio parahaemolyticus and related to the thermostable direct hemolysin. Infect Immun 56, 961-965.

Honda, T., Honda, S., Ni, V. \& Miwatani, T. (1990a). Development and application of enzyme-linked immunosorbent assay using monoclonal antibody against a hemolysin (Vp-TRH) of Vibrio parahaemolyticus - evidence that Vp-TRH-producing Kanagawa-phenomenon-negative $V$. parahaemolyticus is a human pathogen. Kansenshogaku Zasshi 64, 767-773.

Honda, T., Ni, Y., Hata, A., Yoh, M., Miwatani, T., Okamoto, T., Goshima, K., Takakura, H., Tsunasawa, S. \& Sakiyama, F. (1990b). Properties of a hemolysin related to the thermostable direct hemolysin produced by a Kanagawa phenomenon negative, clinical isolate of Vibrio parahaemolyticus. Can J Microbiol 36, 396-399.

lida, T. \& Yamamoto, T. (1990). Cloning and expression of two genes encoding highly homologous hemolysins from a Kanagawaphenomenon-positive Vibrio parahaemolyticus T4750 strain. Gene 93, 9-15.

lida, T., Suthienkul, O., Park, K.-S., Tang, G.-Q., Yamamoto, R. K., Ishibashi, M., Yamamoto, K. \& Honda, T. (1997). Evidence for genetic linkage between the ure and trh genes in Vibrio parahaemolyticus. J Med Microbiol 46, 639-645.

Kado, C. I. \& Liu, S. T. (1981). Rapid procedure for detection and isolation of large and small plasmids. J Bacteriol 145, 1365-1373.

Magalhaes, M., Takeda, Y., Magalhaes, V. \& Tateno, S. (1992). Brazilian urease-positive strains of Vibrio parahaemolyticus carry genetic potential to produce the TDH-related hemolysin. Mem Inst Oswaldo Cruz 87, 167-168.

Miyamoto, Y., Kato, T., Obara, S., Akiyama, S., Takizawa, K. \& Yamai, S. (1969). In vitro hemolytic characteristic of Vibrio parahaemolyticus: its close correlation with human pathogenicity. J Bacteriol 100, 1147-1149.

Mobley, H. L. T., Island, M. D. \& Hausinger, R. P. (1995). Molecular biology of microbial ureases. Microbiol Rev 59, 451-480.

Nicholson, E. B., Concaugh, E. A., Foxall, P. A., Island, M. D. \& Mobley, H. L. T. (1993). Proteus mirabilis urease: transcriptional regulation by UreR. J Bacteriol 175, 465-473.

Nishibuchi, M. \& Kaper, J. B. (1995). Thermostable direct hemolysin gene of Vibrio parahaemolyticus: a virulence gene acquired by a marine bacterium. Infect Immun 63, 2093-2099.

Nishibuchi, M., Fasano, A., Russell, R. G. \& Kaper, J. B. (1992). Enterotoxigenicity of Vibrio parahaemolyticus with and without genes encoding thermostable direct hemolysin. Infect Immun $\mathbf{6 0}$, $3539-3545$.
Obata, H., Kai, A., Sekiguchi, K., Matsushita, S., Yamada, S., Ito, T., Ohta, K. \& Kudoh, Y. (1996). Detection of the trh gene in Vibrio parabaemolyticus isolated from overseas travelers' diarrhea and their biochemical characteristics. Kansenshogaku Zasshi 70, 815-820.

Okuda, J., Ishibashi, M., Abbott, S. L., Janda, J. M. \& Nishibuchi, M. (1997). Analysis of the thermostable direct hemolysin $(t d h)$ gene and the $t d h$-related hemolysin $(t r h)$ genes in urease-positive strains of Vibrio parahaemolyticus isolated on the West Coast of the United States. J Clin Microbiol 35, 1965-1971.

Osawa, R., Okitsu, T., Morozumi, H. \& Yamai, S. (1996). Occurrence of urease-positive Vibrio parahaemolyticus in Kanagawa, Japan, with specific reference to presence of thermostable direct hemolysin (TDH) and the TDH-related-hemolysin genes. Appl Environ Microbiol 62, 725-727.

Sakazaki, R., Tamura, K., Kato, T., Obara, Y., Yamai, S. \& Hobo, K. (1968). Studies on the enteropathogenic, facultatively halophilic bacteria, Vibrio parahaemolyticus. III. Enteropathogenicity. Jpn J Med Sci Biol 21, 325-331.

Shirai, H., Ito, H., Hirayama, T., Nakamoto, Y., Nakabayashi, N., Kumagai, K., Takeda, Y. \& Nishibuchi, M. (1990). Molecular epidemiologic evidence for association of thermostable direct hemolysin (TDH) and TDH-related hemolysin of Vibrio parahaemolyticus with gastroenteritis. Infect Immun 58, 3568-3573.

Smith, C. L. \& Cantor, C. R. (1987). Purification, specific fragmentation, and separation of large DNA molecules. Methods Enzymol 155, 449-467.

Suthienkul, O., Ishibashi, M., lida, T., Nettip, N., Supavej, S., Eampokalap, B., Makino, M. \& Honda, T. (1995). Urease production correlates with possession of the trh gene in Vibrio parabaemolyticus strains isolated in Thailand. J Infect Dis 172, 1405-1408.

Suthienkul, O., lida, T., Park, K.-S., Ishibashi, M., Supavej, S., Yamamoto, K. \& Honda, T. (1996). Restriction fragment length polymorphism of the $t d h$ and $t r h$ genes in clinical Vibrio parahaemolyticus strains. J Clin Microbiol 34, 1293-1295.

Suzuki, N., Ueda, Y., Mori, H. \& 8 other authors (1995). Correlation between trh possession and urease production of clinical isolates of Vibrio parahaemolyticus. Kansenshogaku Zasshi 69, 757-758.

Terai, A., Baba, K., Shirai, H., Yoshida, O., Takeda, Y. \& Nishibuchi, M. (1991). Evidence for insertion sequence-mediated spread of the thermostable direct hemolysin gene among Vibrio species. $J$ Bacteriol 173, 5036-5046.

Wilson, K. (1987). Preparation of genomic DNA from bacteria. In Current Protocols in Molecular Biology, vol. 1, pp. 2.4.1-2.4.2. Edited by F. M. Ausubel and others. New York: Wiley.

Xu, M., Yamamoto, K. \& Honda, T. (1994). Construction and characterization of an isogenic mutant of Vibrio parahaemolyticus having a deletion in the thermostable direct hemolysinrelated hemolysin gene (trh). J Bacteriol 176, 4757-4760.

Received 2 February 1998; revised 29 April 1998; accepted 1 June 1998. 